\title{
Implementation Of Thematic Learning In Raudhatul Atfhal Al-Ghazali Medan
}

\author{
Rusydi Ananda ${ }^{1}$, Nurul Hafizah ${ }^{2}$ \\ 1 FITK UIN SU Medan, Indonesia \\ 2 FITK UIN SU Medan, Indonesia
}

Corresponding Author: $\otimes$ rusydiananda@uinsu.ac.id

\section{ABSTRACT}

The research objectives are to find out: (1) thematic learning planning (2) implementation of thematic learning (3) evaluation of thematic learning and (4) Supporting and inhibiting factors of thematic learning in Raudhatul Athfal Al-Ghazali Medan. The study was conducted at Raudhatul Athfal Al-Ghazali Medan. The method used is a qualitative research method. Data sources are the principal, teachers and students. Data retrieved through observation, documentation, and interviews. Data are analyzed based on data reduction, data presentation, and conclusions.

\section{ARTICLE INFO \\ Article history: \\ Received}

12 Oktober 2020

Revised

15 Oktober 2020

Accepted

20 Oktober 2020
Kata Kunci

Keywords

How to cite
Research findings show; (1) Thematic learning planning conducted by Raudhatul Atfhal Al-Ghazali Medan teacher is to prepare plan learning at the beginning of the semester by considering competency standards, core competencies, mission vision and school goals as well as the needs of children and activities close to the child's daily life. Furthermore, the plan learning and reported at the teacher meeting to get input from colleagues and head of Raudhatul Atfhal Al-Ghazali Medan, (2) the implementation of thematic learning at Raudhatul Atfhal Al-Ghazali Medan was carried out with exemplary learning methods, role playing, giving examples, lectures, discussion and observation. The learning method used is interesting to be followed by children, and children can be enthusiastic in following the learning process carried out, (3) evaluation of learning towards thematic learning at Raudhatul Atfhal Al-Ghazali Medan by providing a portfolio, in this case evaluating changes in behavior, children also can experience positive changes in his behavior after following the thematic learning process by the teacher Raudhatul Atfhal Al-Ghazali Medan.

Thematic Learning, Raudhatul Atfhal

Name. (2020). Tittle. Journal Continuous Education, 1(1). 1-10.

http:// pusdikra-publishing.com/index.php/josr/issue/current

\section{INTRODUCTION}

Thematic learning is the packaging of lessons in a theme that contains several areas of competence that children learn, so that the abilities acquired by children can be diverse, not necessarily the same for each child. The uniqueness of each child must be respected. Some children may be able to read ahead of 
other children and that is not a concern. Every child doesn't have to take the same path in learning something.

Thematic learning is a way to not limit children in a "subject", in learning something. For example, while learning to sing someone the child learns the alphabet. Or while learning to know animals he also learns to color. Learn to recognize wild plants while hiking. Learning many things at once in one big theme trains to connect what he has learned into a large, complete picture. Besides the child's boredom for a subject can be reduced because of the many variations. Maybe a child does not like to count, but because counting is packaged in a game, children become interested in the game. Freedom of expression of children also has more place (Mappasoro, 2008)

Thematic learning is also intended to provide meaningful experiences to children, because in thematic learning, children understand various concepts that they learn through direct experience and connect with concepts they have mastered without eliminating the element of play that is indeed "the world" of children. In accordance with the characteristics of learning in Raudhatul Athfal, increasing the competence of children's religious knowledge and morals is done through play. Therefore, increasing the competence of children's religious knowledge and morals can be done by the teacher in thematic learning activities simultaneously, for example the teacher shows some toy objects which among the game objects there are hidden letters placed in different areas such as religious music Islam, the area of Islamic Religious Education, the area of blocks, but is bound to a common theme as demanded for thematic learning. Then increase to the hidden words contained in these areas that can be read by children. After the process is passed, the teacher invites children to sing according to the material being learned. The point is that through play activities carried out by children there is an element in increasing the competence of children.

(Mardianto, 2011) explains that thematic learning is integrated learning that uses themes to link several subjects so as to provide meaningful experiences to children. Meanwhile (Sungkono, 2006) states that thematic learning is defined as a learning activity by integrating the material of several subjects into one discussion theme. The same thing was also expressed by (Sutirjo \& Mamik, 2005) stating thematic learning is an attempt to integrate knowledge, skills, values or attitudes of learning and creative thinking using themes.

The thematic learning characteristics described by the Ministry of (Nasional, 2006) are: (1) learning experiences and activities are very relevant to the level of development and needs of children, (2) the activities chosen in the implementation of thematic learning are based on children's interests and needs, (3) learning activities will be more meaningful and memorable for children so that learning outcomes can last longer, (4) help develop children's thinking skills, (5) present pragmatic learning activities in accordance with problems that are often encountered by children in their environment, and (6) 
develop children's social skills, such as cooperation, tolerance, communication, and responsiveness to the ideas of others. Implementation of learning by utilizing this theme, several benefits will be obtained as explained by the Ministry of (Nasional, 2009) namely: (1) by combining some basic competencies and indicators as well as subject matter there will be savings, because overlapping material can be reduced or even eliminated, (2) children are able to see meaningful relationships because learning content / materials play a role as a means or tool, not an end, (3) learning becomes whole so that children will get an understanding of processes and materials that are not fragmented, (4) with the integration of subjects, mastery of concepts will be better and improved.

(Tukimo, 2005) state the benefits of thematic learning are: (1) children easily focus on specific themes or topics, (2) children can develop various competencies in certain subjects or topics, (3) understanding of subject matter is more in-depth and memorable, (4) language competence can be developed better by linking various aspects of children's abilities and personal experiences, (5) children feel and learn meaning more because the material is presented in the context of a clear theme, (6) children are more passionate about learning because they can communicate in real situations to develop language skills as well as to learn other subjects, for example asking questions, telling stories, drawing, (7) teachers can save time because subjects that are presented in an integrated manner can be simultaneously and given in two or three meetings. Excess time can be used for remedial activities, settling and enrichment, (8) developing mental and physical abilities and skills in an integrated and optimal manner, and (9) children's character and morals can be instilled by raising a number of values in accordance with the situation and conditions.

(Sudimahayasa, 2015) Thematic learning has implications for teachers to be creative both in preparing learning activities/experiences for children, as well as in selecting competencies from various subjects and organizing them so that learning becomes more meaningful, interesting, enjoyable and whole. The implications of thematic learning for facilities, infrastructure, learning resources and media as explained by the Ministry of (Nasional, 2006) namely: (1) thematic learning essentially emphasizes children both individually and in groups to actively seek, explore and find concepts and principles - principles holistically and authentically. Therefore, in its implementation requires a variety of learning facilities and infrastructure, (2) this learning needs to utilize a variety of learning resources that are specifically designed for the purposes of implementing learning (by design) in Raudhatul Athfal, as well as learning resources available in an environment that can utilized (by utilization) in learning activities, and (3) this learning also needs to optimize the use of various learning media so that it will help children understand abstract concepts, and (4) the application of thematic learning can still use existing textbooks for each subject and it is possible also to use a special supplement book that contains integrated teaching materials. 
(Amin et al., 2018) Assessment in thematic learning is an attempt to obtain various information regularly, continuously, and thoroughly about the process and results of growth and development that have been achieved by students through learning activities programs (Solihah, 2016). The objectives of the thematic learning assessment explained (Sukayati, 2004) are: (1) knowing the achievement of predetermined indicators, (2) obtaining feedback for the teacher, for knowing the obstacles that occur in learning and learning effectiveness, (3) obtaining a clear picture about the development of children's knowledge, skills and attitudes, and (4) as a reference in determining follow-up plans (remedial, enrichment, and stabilization).

Assessment tools can be in the form of tests and non-tests. The test includes: written, oral, or deed, a diary of the child's development, and a portfolio. In learning activities at Raudhatul Athfal, the assessment that is more widely used is through assignments and portfolios. Non-test assessment is done by the teacher to assess the child through observations which are then recorded in a handbook.

\section{RESEARCH METHODE}

The method used is a qualitative research method. Data sources are the principal, teachers and students. Data retrieved through observation, documentation, and interviews. Data are analyzed based on data reduction, data presentation, and conclusions

\section{RESULT AND DISCUSSION}

The thematic learning process at Raudhatul Atfhal Al-Ghazali Medan is arried out with exemplary learning methods, role playing, giving examples, lecturing, discussing, and observing. The learning method used is interesting to be followed by students, and students can be enthusiastic in following the learning process carried out.

The learning that was carried out at Raudhatul Atfhal Al-Ghazali Medan was intended to increase spiritual potential and form students to become people of faith and devotion to God Almighty and of good character. Noble character includes ethics, character, and morals as an embodiment of education. The increase in spiritual potential includes the introduction, understanding and inculcation of religious values, as well as the practice of these values in individual or collective community life.

The increase in spiritual potential is ultimately aimed at optimizing the various potentials possessed by humans whose actualization reflects their dignity and dignity as God's creatures. Education is given by following the guidance that religion is taught to humans with a vision to realize people who are devoted to Allah SWT and have good character, and aim to produce people 
who are honest, just, virtuous, ethical, respectful, disciplined, harmonious and productive, good personal and social.

Education given to Raudhatul Atfhal Al-Ghazali's children in Medan is expected to produce people who always strive to perfect faith, piety, and morals, and actively build civilization and harmony of life, especially in advancing the dignified nation's civilization. Such human beings are expected to be resilient in facing challenges, obstacles, and changes that arise in the association of society both locally, nationally, regionally and globally.

For this reason, Raudhatul Atfhal Al-Ghazali Medan teacher is expected to be able to develop learning methods in accordance with competency standards and basic competencies. Achievement of all the basic competencies of commendable behavior can be done irregularly. The role of all elements of the school. Parents of students and the community are very important in supporting the successful achievement of educational goals in Raudhatul Atfhal Al-Ghazali Medan.

The success of a learning is determined by the teacher's competence in preparing, implementing, evaluating, and providing "feed back". That is, the quality of learning with the teacher as the implementer is crucial to the success of a learning. There are at least 3 factors that influence learning success, namely the goal factor, teacher factor, and student or student factors.

In this case, the components of the Islamic education system contain at least educational objectives, educational curriculum, educators, students, educational methods, and educational evaluations. In order to achieve the educational objectives at Raudhatul Atfhal Al-Ghazali Medan, the above components must be set in order to achieve their goals. Children's potential, be it cognitive, effective, and psychomotor aspects must be truly achieved. So that children know what Islam is, skilled in carrying out Islamic sharia, and most importantly, the values of Islamic teachings internally within students.

The education carried out at Raudhatul Atfhal Al-Ghazali Medan in the context of human resource development focuses on learning new skills, knowledge and attitudes, which will equip individuals to assume new jobs or to carry out different tasks previously planned in the future. The participation of a child formally follows the level of education, is assumed to provide an opportunity for him to change more from things that do not know to know, from not good to good to from unskilled to skilled. For this reason, the high level of formal education of a person until now is believed to be an indicator of the breadth of knowledge.

Implementation of thematic learning conducted by Raudhatul Atfhal AlGhazali Medan democratically by involving students in decision making, the value of curiosity by means of enriching learning material, the value of national spirit by working with different classmates without knowing ethnicity, 
ethnicity, status socio-economic, the value of patriotism by means of the class attached photos of the president and vice president, flags and symbols of the State, encouraging the use of products made in the country, the value of respecting achievements by giving appreciation to students who get achievements both academically and academically, grades friendly/communicative with the way students interact, dialogic learning.

Meanwhile the implementation of the value of peace in learning by means of interaction occurs learners, teachers in solving problems using dialogue, the value of reading likes by encouraging students to be happy to read both before or after learning, the value of caring for the environment by planting trees in the school environment, and throwing sprouts according to their type in the trash, the value of social care by praying, visiting, and infaqity for friends who have a disaster, and responsibility by doing the work. Based on the implementation of education carried out at Raudhatul Atfhal Al-Ghazali Medan through activities developing religious character values, honesty, tolerance, discipline, hard work, creative, independent, democratic, curiosity, national spirit, love of the motherland, respect for achievement, friendly/ communicative, peace-loving, fond of reading, caring for the environment, caring socially, and responsible for learning in class.

Character values are adjusted to competencies and indicators. In the implementation of character education activities that are already carried out are then strengthened, and can also hold new activities. From the character values developed by the Ministry of National Education, the implementation of thematic learning has all been carried out in accordance with the competencies and material indicators delivered by the teacher. Then for the value of curiosity, the child of Raudhatul Atfhal Al-Ghazali Medan is expected to be more free in expressing curiosity by holding mentoring and Islamic discussion. Through this media, researchers see that students who follow will be answered curiosity, while for students who are seniors will know better, because they are required to guide their class juniors.

The scope of religious competence and noble morality is a learning curriculum that is intended to increase the spiritual potential of students through examples of experiences from educators to become daily habits both inside and outside of school so that they become part of the school culture. Furthermore, related to the scope of the curriculum on aspects of Islam that are given in are: know the pillars of faith and pillars of Islam, know God and its attributes, know the prophets and messengers of God, know the scriptures, say 2 sentences creed, know prayer and be able to run it, know meaning of zakat, knowing fasting and practicing it, knowing Ied prayer and practicing it, knowing the pilgrimage and practicing it, knowing sacrifice, short surahs, daily prayers and thayyibah sentences. 
While relating to the scope of the curriculum in the aspects of morals, namely God's moral code of conduct, know the moral code of conduct for others, know the moral code of behavior towards animals and nature, show an attitude of discipline, be responsible, show an attitude of independence, control feelings and show confidence.

The implementation of Islamic religious competence curriculum and morals that are packaged in the learning program pays attention to the principles of curriculum implementation as follows: (1) creating a safe, comfortable, clean and attractive atmosphere, (2) child-centered learning and implemented interactively, inspiratively, pleasantly and encouragingly creativity and independence, (3) in accordance with the stage of physical growth and mental development of children and the best needs and interests of children, (3) pay attention to differences in talents, interests and abilities of each child, (4) integrating children's needs on health. nutrition, stimulation, psychosocial and attention to the economic, social and cultural background of the child, (5) learning is carried out through play, choosing appropriate and varied play methods and tools, and utilizing various sources in the environment, (6) learning activities carried out in stages, continuous and accustomed nature, (7) selection of techniques and assessment tools in accordance with the activities carried out, and (8) activities provided in accordance with the characteristics and needs of the child's development.

The findings of this study are related to the role of thematic learning supporting the results of previous studies conducted (Thamrin \& Ali, 2015) : (1) show that the preparation of thematic learning plans for children can be carried out in a variety of themes. The methods used by the teacher in thematic learning are storytelling, conversation, demonstration, assignment, projects, and field trips. While the media used are picture books, television, various playing instruments, used goods, blackboards, (2) (Ananda \& Abdillah, 2018) shows the technical implementation of developing moral and religious values in children formally conducted 15-20 minutes every day before learning activities begins with the form of activities using the lecture method (explaining the concept), through games, telling stories, singing, exemplary, role playing, field trips, (3) (Tanfidiyah, 2017) shows the development of religion and morals that are not achieved in early childhood including those concerning religion and God through singing, not getting used to worship, not understanding noble behavior, not being able to distinguish good and bad behavior, and very little about religious rituals and not knowing Islamic holidays, and not knowing other religions, (4) (Apriyanti, 2017) shows average the average understanding of early childhood education teachers towards thematic learning planning by $76 \%$ so that it can be educated the teacher Raudhatul Atfhal at Ajung subdistrict already understood the aspects of thematic learning planning, and (5) (Nurjannah, 2018) showed that the development of religious and moral values of the subject had been achieved in accordance with the standard level of child 
development achievement related to their ability to understand and conduct good behavior and to understand good behavior and avoiding bad behavior based on religious teachings that are believed. This is inseparable from the role of parents and then the parents with the school and the surrounding environment.

Specifically, the impact of thematic learning on children's character Raudhatul Atfhal Al-Ghazali Medan can display attitudes and behaviors in the form of: (1) caring consists of helping others who need help, being responsive to the surrounding environment, cleaning the classroom, tidying tables / chairs scattered about, and keep the school environment clean, (2) politeness consists of greeting, speaking politely with friends and teachers, speaking and behaving politely and not bragging, and asking permission when leaving the classroom and leaving school, (3) respecting diversity consists of recognizing differences in ethnicity and economic background and, carrying out religious activities without offending and disturbing others, and not imposing opinions/ideas on others, and (4) adherence to social rules that apply at school consists of following community service at school, participate in activities managed by the school, participate in maintaining peace and comfort in the school da $\mathrm{n}$ obey the discipline rules imposed by the school.

Looking at the characters that appear from the research findings formed from the characters displayed by students, this is actually the effort of all components of the school, both school principals and Raudhatul Atfhal AlGhazali Medan teachers, this is in line explanation that Character education is everything that teachers do that is able to influence student character.

\section{CONCLUSION}

The conclusions of the study are: (1) thematic learning planning conducted by Raudhatul Atfhal Al-Ghazali Medan teacher is to prepare a daily learning implementation plan at the beginning of the semester by considering competency standards, core competencies, vision and mission goals of the school and the needs of children and activities close to children's daily lives, (2) the implementation of thematic learning at Raudhatul Atfhal Al-Ghazali Medan is carried out with exemplary learning methods, role playing, giving examples, lectures, discussions, and observations. The learning method used is interesting to be followed by children, and children can enthusiastically participate in the learning process carried out, and (3) evaluation of learning towards thematic learning at Raudhatul Atfhal Al-Ghazali Medan by providing a portfolio, in this case evaluating changes in behavior, children can also experience positive changes in behavior after following the thematic learning process conducted by the teacher Raudhatul Atfhal Al-Ghazali Medan.

Recommendations that can be delivered are: (1) To the head of Raudhatul Atfhal Al-Ghazali Medan, it should be able to meet various facilities and infrastructure such as infocus that can support the learning process in 
Journal Continuous Education

Volume 1, Issue 1, November 2020

Page 1-10

schools by planning their allocation in the budget plan, (2) To the head of Raudhatul Atfhal Al-Ghazali Medan so that it can facilitate teachers in involving teachers in training conducted by the Ministry of Religion or other institutions, (3) To the teacher Raudhatul Atfhal Al-Ghazali Medan so that it can increase innovations in managing thematic learning through individual reading activities, attend training and seminars, so that thematic learning activities can be more interesting and fun, and (4) to the next researcher, so that it can be researched about thematic learning outside the focus of research examined in this study.

\section{ACKNOWLEDGEMENT}

thanks to all those who have helped complete this research, as well as contributed to researchers in Raudhatul Atfhal Al-Ghazali Medan.

\section{REFERENCES}

Amin, T. A., Yahya, M., \& Carong, M. W. (2018). Penerapan Model Pembelajaran Kooperatif Tipe Tgt Untuk Meningkatkan Hasil Belajar Membiakkan Tanaman Secara Vegetatif Pada Siswa Kelas X Smk Negeri 3 Takalar. Jurnal Pendidikan Teknologi Pertanian, 4, 73-81. https://ojs.unm.ac.id/index.php/ptp/article/viewFile/6614/3762

Ananda, R., \& Abdillah. (2018). Pembelajaran Terpadu. Karakteristik, Landasan, Fungsi, Prinsip Dan Model, Medan. Lembaga Peduli Pengembangan Pendidikan Indonesia (LPPPI).

Apriyanti, H. (2017). Pemahaman Guru Pendidikan. Anak Usia Dini Terhadap Perencanaan Pembelajaran Tematik. Jurnal Obsesi, 2.

Mappasoro. (2008). Pembelajaran Tematik Modul PLPG Rayon 24. Universitas Negeri Makasar.

Mardianto. (2011). Pembelajaran Tematik. Perdana Publishing.

Nasional, K. P. (2006). Model Tematik Kelas Awal. Badan Standar Nasional Pendidikan.

Nasional, K. P. (2009). Peraturan Menteri Pendidikan Nasional No. 58 Tahun 2009 Tentang Standar Pendidikan Anak Usia Dini, Jakarta; Direktorat Pendidikan Anak Usia Dini. Direktorat Jenderal Pendidikan Nonformal dan Informal.

Nurjannah, S. (2018). Perkembangan Nilai Agama Dan Moral. Jurnal Paramurobi, 1(1).

Solihah, A. (2016). Pengaruh Model Pembelajaran Teams Games Tournament (Tgt) Terhadap Hasil Belajar Matematika. Jurnal SAP, 1(1), 45-53. http://journal.lppmunindra.ac.id/index.php/SAP/article/download/101 $0 / 942$

Sudimahayasa, N. (2015). Penerapan Model Pembelajaran Tgt Untuk Meningkatkan Hasil Belajar, Partisipasi, Dan Sikap Siswa. Jurnal Pendidikan Dan Pengajaran, 48(1-3), 45-53. https:/ / ejournal.undiksha.ac.id/index.php/JPP/article/view/6917 
Journal Continuous Education

Volume 1, Issue 1, November 2020

Page 1-10

Sukayati. (2004). Pembelajaran Tematik di SD Merupakan Terapan Dari Pembelajaran Terpadu. Pusat Pengembangan Penataran Guru (PPPG) Yogyakarta.

Sungkono. (2006). Pembelajaran Tematik Dan Implementasinya Di Sekolah Dasar. Majalah Ilmiah Pembelajaran Jurusan Kurikulum Dan Teknologi Pendidikan. $\mathrm{UNY}$.

Sutirjo, \& Mamik. (2005). Tematik: Pembelajaran Efektif Dalam Kurikulum 2004. Bayumedia Publishing.

Tanfidiyah, N. (2017). Perkembangan Agama Dan Moral Yang Tidak Tercapai Pada Anak Usia Dini. Studi Kasus di Kelas A1 TK Masyitoh Ndasari Budi Yogyakarta. Nadwa, 11(2).

Thamrin, \& Ali. (2015). Pelaksanaan Pembelajaran Tematik Pada Anak Usia 5-6 Tahun. Jurnal Pendidikan Dan Pembelajaran Khatulistiwa, 4(5).

Tukimo. (2005). Buku Pegangan Guru Perangkat Pembelajaran Tematik. Tekindo Utama.

Zaini, M. F. (2019). The Implementation Of Learning Management In Class Viii Madrasa Tsanawiyah Islamiyah (Mts) Ypi Batangkuis. International Conference on Islamic Educational Management (ICIEM). 